\title{
Physiological, morphological, and mannanase production studies on Aspergillus niger uam-gs1 mutants
}

\author{
Soledad De Nicolás-Santiago \\ Departamento de Biotecnología \\ Universidad Autónoma Metropolitana-Iztapalapa \\ Av. San Rafael Atlixco 186, Iztapalapa \\ 09340 Mé xico D.F., México \\ Tel: 525558044999 \\ Fax: 525558044712 \\ E-mail:sol@xanum.uam.mx \\ Carlos Regalado-González \\ DIPA, PROPAC \\ Facultad de Química \\ Universidad Autónoma de Querétaro \\ CU. Cerro de las Campanas S/N \\ 76010 Querétaro, Qro. México \\ Tel/Fax: 524421921304 \\ E-mail: carlosr@uaq.mx

\section{Blanca García-Almendárez \\ DIPA, PROPAC \\ Facultad de Química \\ Universidad Autónoma de Querétaro \\ CU. Cerro de las Campanas S/N \\ 76010 Querétaro, Qro. México \\ Tel/Fax: 524421921304 \\ E-mail: blancag@uaq.mx}

\section{Francisco J. Fernández} \\ Departamento de Biotecnología \\ Universidad Autónoma Metropolitana-Iztapalapa \\ Av. San Rafael Atlixco 186, Iztapalapa \\ 09340 México D.F., México \\ Tel: 525558046453 \\ Fax: 525558044712 \\ E-mail: fjfp@xanum.uam.mx

\section{Alejandro Téllez-Jurado} \\ Departamento de Biotecnología \\ Universidad Politécnica de Pachuca \\ Ex-Hacienda de Sta. Bárbara \\ Carretera Pachuca-Cd. Sahagún, km. 20 \\ Zempoala, Hidalgo, Mexico \\ Tel/Fax: 527437911800 \\ E-mail: alito@upp.edu.mx

\section{Sergio Huerta-Ochoa*} \\ Departamento de Biotecnología \\ Universidad Autónoma Metropolitana-Iztapalapa \\ Av. San Rafael Atlixco 186, Iztapalapa \\ 09340 México D.F., México \\ Tel: 525558044999 \\ Fax: 525558044712 \\ E-mail: sho@xanum.uam.mx
}

Financial support: Universidad Autónoma Metropolitana -Iztapalapa, México.

Keywords: Aspergillus niger, mutation, mannanase production.

$\begin{array}{ll}\text { Abbreviations: } & \text { PDA: potato dextrose agar } \\ & \text { SSF: solid-state fermentation }\end{array}$

*Corresponding author 
Mutant strains from Aspergillus niger UAM-GS1 were produced by UV radiation to increase their hemicellulolytic and cellulolytic activity production. The mutant strains showing more enzymatic activity were those labelled GS1-S059 and GS1-S067. These strains also showed the largest relationship between diameter of hydrolysis zone and colony diameter. The mutant GS1-S067 showed a colony radial extension rate and a biomass growth rate $\left[\mathrm{g}\right.$ biomass $\left./\left(\mathrm{cm}^{2} \mathrm{~h}\right)\right], 1.17$ times higher than that achieved by strain UAM-GS1. The high invasive capacity makes this mutant strain a promising alternative for its use in solid substrate fermentation (SSF). The morphological properties of the two mutant strains were evaluated by using scanning electron microscopy. The diameter of the sporangium of the mutant strains GS1-S059 and GS1S067 was significantly larger $(P<0.05)$ than that found for the parental strain. The hypha length and diameter of the mutant strains significantly changed $(P<0.05)$ compared to the parental strain. A Pearson correlation analysis on hypha length, sporangium diameter, and cellulase and xylanase activities indicated that there was a strong relationship among these variables in relation to mannanase activity. Mutant strains GS1-S059 and GS1-S067 significantly increased their level of mannanase, xylanase and cellulase production, compared to the parental strain, improving their potential industrial applications.

Filamentous fungi are important in industrial enzyme production, since they are able to synthesize and secrete large amounts of extra cellular proteins. These organisms grow in liquid and solid-state cultures by hyphal extension and branching. The importance of morphological and physiological studies on fungi in liquid cultures has been recently reviewed (Papagianni, 2004). Fungal macro- and micro-morphology affect the rheology of the fermentation medium, thereby having a significant impact on the mixing, mass transfer and aeration processes within the bioreactor. In addition, micro-morphology may influence metabolite productivity, which may lead to lower net specific growth rate (McIntyre et al. 2001), or to enhanced enzyme production by strains with altered morphology (McCarthy et al. 2005).

The potential of enzyme production by fungi using solidstate fermentation (SSF) techniques has been discussed (Viniegra-González, 1998). The difference of conditions between solid-state and submerged cultures can lead to altered expression of several genes, which in turn may affect various phenotypes, such as growth, development, mycotoxin and enzyme production (Iwashita, 2002). The advantages of fungal enzyme production in solid-state over liquid fermentation systems have also been pointed out (Viniegra-González et al. 2003). However, few criteria about fungal physiology and morphology in solid-state cultures have been established in the limited studies

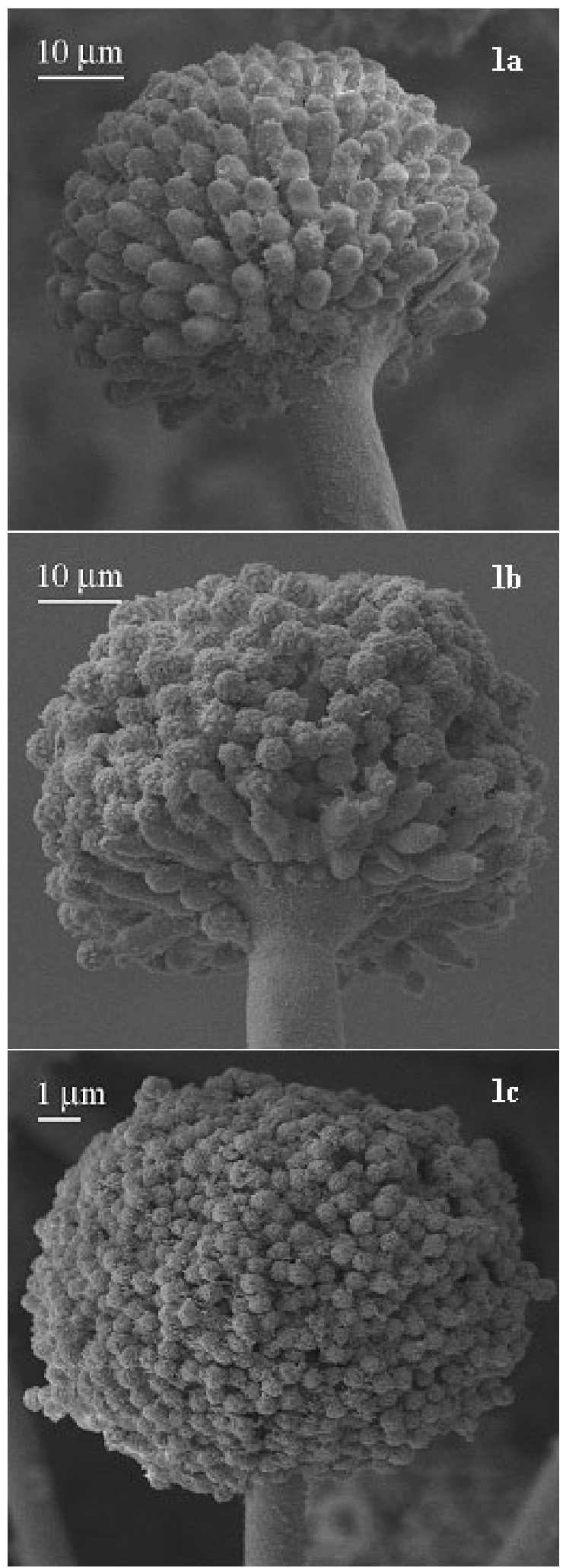

Figure 1. Scanning electron micrograph of sporangia from: (a) A. niger parental.

(b) mutant strains GS1-059.

(c) mutant strains GS1-067. 
Table 1. Mannanase activity zone and colony growth of parental and mutant Aspergillus niger strains (First selection).

\begin{tabular}{|c|c|c|c|}
\hline $\begin{array}{c}\text { Aspergillus niger } \\
\text { strains }\end{array}$ & $\begin{array}{c}\text { Colony diameter } \\
(\mathbf{c m})\end{array}$ & $\begin{array}{c}\text { Zone of activity } \\
(\mathbf{c m})\end{array}$ & Zone/colony diameter \\
\hline UAM-GS1 & $1.0 \pm 0.01$ & $1.3 \pm 0.005$ & $1.30 \pm 0.001$ \\
\hline GS1-S047 & $0.9 \pm 0.01$ & $1.4 \pm 0.001$ & $1.56 \pm 0.002$ \\
\hline GS1-S048 & $0.6 \pm 0.01$ & $1.0 \pm 0.001$ & $1.67 \pm 0.001$ \\
\hline GS1-S059 & $1.0 \pm 0.01$ & $1.8 \pm 0.011$ & $1.80 \pm 0.010$ \\
\hline GS1-S064 & $1.0 \pm 0.01$ & $1.4 \pm 0.011$ & $1.40 \pm 0.001$ \\
\hline GS1-S067 & $1.0 \pm 0.01$ & $1.7 \pm 0.012$ & $1.70 \pm 0.001$ \\
\hline
\end{tabular}

available. For instance, Trinci (1973) working with Neurospora crassa in solid culture defined the hyphal growth unit (total hyphal length/number of hyphal tips) as a measurement of the fungal invasive capacity. In contrast, Ferret et al. (1999), used the colony radial extension rate obtained by linear regression of colony diameter versus time. There are few studies relating morphology and physiology of fungi in solid-state cultures.

On the other hand, strain improvement has been achieved through mutation, selection, or genetic recombination. In many cases, mutations are harmful, but occasionally may lead to a better adapted organism to its environment with improved biocatalytic performance. The potential of a microorganism to mutate is an important property conferred by DNA, since it creates new variations in the gene pool. The challenge is to isolate those strains which are true mutants that carry beneficial mutations (Parekh et al.2000). UV rays are important inducers of strain mutations. The pyrimidines (thymine and cytosine) are especially sensitive to modifications by UV rays absorption. This may result in the production of thymine dimers that distort the DNA helix and block future replications (Sambrook et al. 2000).

The objective of this study was to characterize physiologically and morphologically Aspergillus niger UAM-GS1 mutants to determine the possible relationship between morphology, growth and mannanase production of the mutant strains. We also aimed to test the mutated strains for increased cellulase and hemicellulase production using a solid-state fermentation process.

\section{MATERIALS AND METHODS}

\section{Microorganism}

Aspergillus niger UAM-GS1 strain, identified by physiological and morphological tests as depicted by Pitt and Hocking (1977), and previously reported (Regalado et al. 2000), was isolated from copra paste in the Biotechnology Department of the Universidad Autónoma Metropolitana. The microorganism was preserved on porcelain pearls (Sigma-Aldrich) at $4^{\circ} \mathrm{C}$.

\section{Strain propagation}

To carry out strain propagation for the mutagenesis experiments, a porcelain pearl was placed in an Erlenmeyer flask containing $30 \mathrm{~mL}$ of potato dextrose agar (PDA) and incubated at $30^{\circ} \mathrm{C}$ during 4 days. Spores were harvested using $50 \mathrm{~mL}$ of a $0.2 \%$ Tween 80 solution and counted in a Neubauer chamber. Spores propagation for SSF experiments was conducted in the selective medium ML1, having the following composition $(\mathrm{g} / \mathrm{L})$ : locust bean gum 6.0 , yeast extract 0.5 , casein peptone $1.0, \mathrm{KH}_{2} \mathrm{PO}_{4}$ 1.0, $\left(\mathrm{NH}_{4}\right)_{2} \mathrm{HPO}_{4}$ 1.0, $\mathrm{MgSO}_{4}$ x 7H2O 0.7, Agar 7.0. Thirty mL of ML1 medium were added to $250 \mathrm{~mL}$ Erlenmeyer flasks, and inoculated with $30 \mu \mathrm{L}$ of a spore suspension obtained from a PDA slant. Inoculated flasks were incubated at $30^{\circ} \mathrm{C}$ during $96 \mathrm{hrs}$, and spores were harvested as mentioned above.

\section{Mutagenesis and strain selection}

Mutagenesis of Aspergillus niger UAM-GS1. The mutagenesis step involved finding the exposure time at which $50 \%$ of the Aspergillus niger UAM-GS1 spores were inactivated by $\mathrm{UV}$ radiation $\left(\mathrm{LD}_{50}\right)$. A. niger UAM-GS1 spores were inoculated in Petri dishes containing PDA and incubated at $30^{\circ} \mathrm{C}$ during 4 days. Spores produced were harvested, counted in a Neubauer chamber and their concentration adjusted to $1 \times 10^{7}$ spores $/ \mathrm{mL}$. Fifteen $\mathrm{mL}$ of the spore suspension were poured into a sterile Petri dish under agitation using a magnetic bar, during the whole procedure. The UV radiation source was placed $15 \mathrm{~cm}$ above the surface of the suspension spores. Radiation intensity was delivered to $350 \mu \mathrm{W} / \mathrm{cm}^{2}$ (Montiel-González et al. 2004). Samples of $1 \mathrm{~mL}$ were taken every min during $30 \mathrm{~min}$, placed in an ice bath for $5 \mathrm{~min}$, kept in the darkness for another $30 \mathrm{~min}$ and diluted to $10^{4} \mathrm{spores} / \mathrm{mL}$. From these dilutions, $100 \mu \mathrm{L}$ were inoculated into Petri dishes containing ML1 medium, and incubated at $30^{\circ} \mathrm{C}$ during 48 hrs, followed by colony count and expressed as colony

Table 2. Mannanase activity (Second selection).

\begin{tabular}{|c|c|}
\hline $\begin{array}{c}\text { Aspergillus } \\
\text { niger strains }\end{array}$ & $\begin{array}{c}\text { Mannanase } \\
\text { activity } \\
\left(\mathbf{U} \mathbf{~ m L}^{-1}\right)\end{array}$ \\
\hline UAM-GS1 & $0.153 \pm 0.021$ \\
\hline GS1-S047 & $0.114 \pm 0.021$ \\
\hline GS1-S048 & $0.170 \pm 0.017$ \\
\hline GS1-S059 & $0.501 \pm 0.017$ \\
\hline GS1-S064 & $0.256 \pm 0.021$ \\
\hline GS1-S067 & $0.438 \pm 0.017$ \\
\hline
\end{tabular}


Table 3. Colony growth and colony radial extension rate $(\mathrm{Kr})$.

\begin{tabular}{|c|c|c|}
\hline Aspergillus niger strains & $\begin{array}{c}\mathbf{K r} \\
\left(\mathbf{m m ~ d ~}^{-1}\right)\end{array}$ & $\begin{array}{c}\text { Biomass growth } \\
\left.\mathbf{( g ~ c m ~}^{-2} \mathbf{~ h}^{-1}\right)\end{array}$ \\
\hline UAM-GS1 & $0.0439 \pm 0.0003(\mathrm{a})$ & $3.541 \times 10^{5}$ \\
\hline GS1-S059 & $0.0402 \pm 0.0003(\mathrm{a})$ & $3.404 \times 10^{5}$ \\
\hline GS1-S067 & $0.0516 \pm 0.0003(\mathrm{~b})$ & $4.117 \times 10^{5}$ \\
\hline
\end{tabular}

Duncan Method $(P<0.05)$. Different letter indicates significant difference.

forming units $(\mathrm{CFU}) / \mathrm{mL}$.

Selection of the hyper producing mutants. The parental and mutant strains were inoculated in Petri dishes containing ML1 medium, covered with cellophane 400, and incubated at $30^{\circ} \mathrm{C}$ during $48 \mathrm{hrs}$. The colonies biomass was collected by removing the cellophane cover, and washing over a filter paper with a $10 \%(\mathrm{w} / \mathrm{v}) \mathrm{NaCl}$ solution. The washed biomass was dried and weighed. Mannanase activity was determined on the surface of the ML1 medium. The strains showing bigger hydrolysis zones were selected (first selection). These strains were used to conduct a SSF employing copra paste as substrate to obtain the enzymatic crude extracts (CE). Thirteen $\mu \mathrm{L}$ of $\mathrm{CE}$ were placed on Whatman No. 41 circular filter papers of $6 \mathrm{~mm}$ in diameter, located over the ML1 medium, and incubated for $30 \mathrm{~min}$ at $50^{\circ} \mathrm{C}$. Enzyme activity was then determined, and the strains showing larger hydrolysis zones were selected, and labelled as hyper producing mutants (second selection).

\section{Enzyme activity determination}

Mannanase activity determination was conducted using the Congo Red method (Downie et al. 1994), with modifications, to obtain a better definition of the activity zones. Since the mycelia interfered with the activity zone definition, a circle of sweet cellophane 400 was placed onto the ML1 medium, covering the Petri dish completely. The inoculum was placed over the cellophane, and was incubated for $48 \mathrm{hrs}$ at $30^{\circ} \mathrm{C}$. After incubation the colonies radii were measured, followed by removal of the cellophane paper containing the biomass. Three $\mathrm{mL}$ of Congo Red was added onto the ML1 medium surface. Petri dishes were slightly manually agitated at $30 \mathrm{sec}$ intervals during $15 \mathrm{~min}$. Extra Congo Red solution was decanted followed by washing of the ML1 medium surface with $\mathrm{NaCl} 0.1 \mathrm{~N}$. After draining the excess liquid from the plates, the hydrolysis zones diameters were measured. A commercial enzymatic extract supplied by SAF-ISIS (France) was used to produce a standard curve using this method. From the extract containing $1,614 \mathrm{U} \mathrm{mL}^{-1}$ of mannanase, solutions containing various mannanase activities $\left(1.614 \times 10^{-2}\right.$ to $\left.161.4 \mathrm{U} \mathrm{mL}^{-1}\right)$ were prepared. The hydrolysis zones diameters produced by the different mannanase activities, measured as mentioned above were evaluated, and the standard curve was obtained by plotting the area of hydrolysis zones (Y-axis) versus mannanase activity $\left(\mathrm{X}\right.$-axis, $\left.\mathrm{U} \mathrm{mL}^{-1}\right)$.
For enzyme (mannanase, xylanase and cellulase) activity determination, $25 \mu \mathrm{L}$ of known amount of substrate (locust bean gum, carboxymetyl cellulose or xylan, respectively) and $25 \mu \mathrm{L}$ enzymatic crude extract, were mixed and incubated during $10 \mathrm{~min}$ at $50^{\circ} \mathrm{C}$. Enzyme reaction was stopped by cooling down the reaction mixture in an ice bath. Reducing sugars were determined by the Nelson (1944) method using mannose as standard.

\section{Radial growth}

RYAM tubes with $20 \mathrm{~mL}$ of ML 1 medium were inoculated by biting an end of the tube, and incubating for 7 days at $30^{\circ} \mathrm{C}$. Radial growth was measured as the length increment of the colony every $24 \mathrm{hrs}$.

\section{Colony growth}

Petri dishes containing the ML 1 medium and a cellophane paper covering the surface, were inoculated by bite (LoeraCorral and Viniegra-González, 1998) from a spore suspension adjusted to $1 \times 10^{7}$ spores $/ \mathrm{mL}$. After incubation during 4 days at $30^{\circ} \mathrm{C}$, cellophane paper was removed and the biomass collected and placed in a previously dried and weighed filter paper. Biomass was washed twice with a $10 \%(\mathrm{w} / \mathrm{v}) \mathrm{NaCl}$ solution, dried during $24 \mathrm{hrs}$ at $60^{\circ} \mathrm{C}$, and weighed. Experiments were conducted in triplicate.

\section{Sporulation level}

Erlenmeyer flasks containing $50 \mathrm{~mL}$ of ML 1 medium were inoculated with $A$. niger UAM-GS1, GS1-S059 and GS1S067 (the last two being the mutants produced in this work). The inoculum added was $1 \times 10^{6}$ spores $/ \mathrm{mL}$, and this was followed by incubation during 4 days at $30^{\circ} \mathrm{C}$. Spores were harvested, and counted using a Neubauer chamber.

\section{Solid-state fermentation}

SSF experiments were carried out using copra paste as substrate and support medium. The substrate was sterilized in autoclave during $15 \mathrm{~min}$ at $121^{\circ} \mathrm{C}$. Sterile substrate was inoculated using a spore concentration of $2 \times 10^{7}$ spores/g of dry matter under sterile conditions. The inoculated substrate was packed in glass columns of $2 \mathrm{~cm}$ in diameter and $20 \mathrm{~cm}$ high. Packed columns were placed in a constant temperature water bath (Raimbault and Alazard, 1980) during $48 \mathrm{hrs}$ at $30^{\circ} \mathrm{C}$. The experiments were carried out in triplicate. 

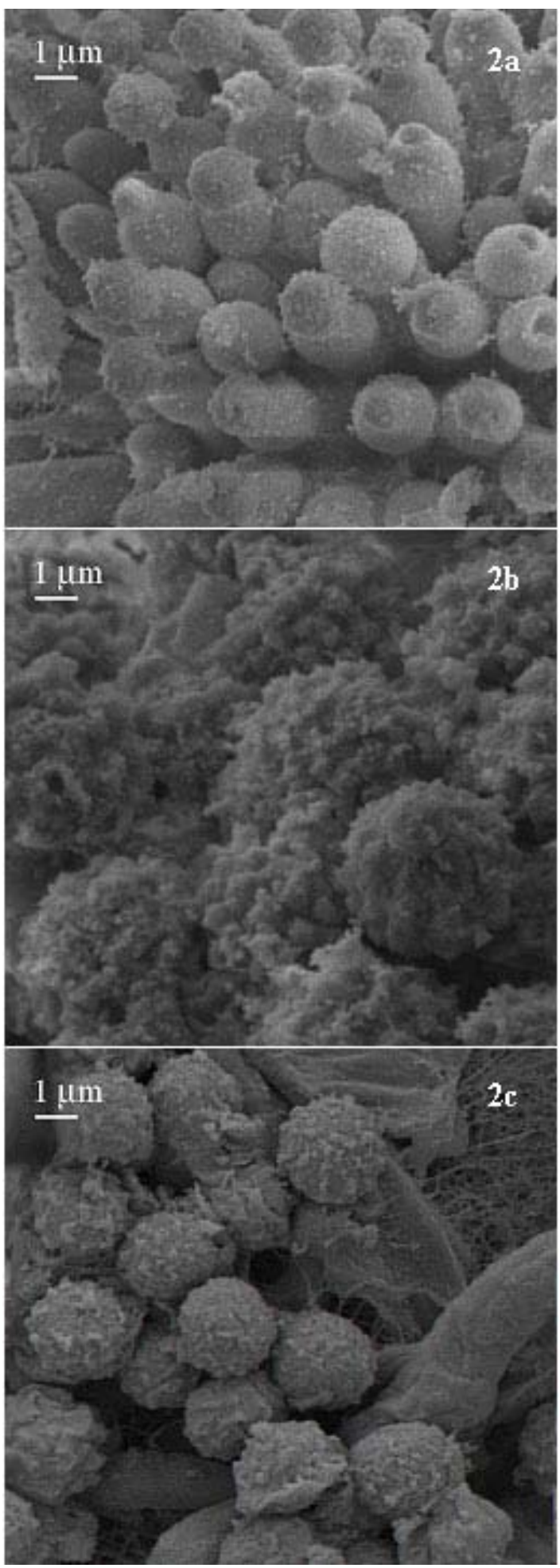

Figure 2. Scanning electron micrograph of spores from:

(a) A. niger parental.

(b) mutant strains GS1-059.

(c) mutant strains GS1-067.

\section{Enzymatic crude extracts}

The fermented material from each column was weighed and acetate buffer $50 \mathrm{mM}, \mathrm{pH} \mathrm{5}$, was added in a 1:1 ratio, and homogenized with a spatula. The crude extract was obtained by using a hydraulic press (ERKCO model PH51T) to a pressure of 2,000 psi. The extracts were filtered through a Whatman No 41 paper, and the amount of mannanase, xylanase and cellulase activities were evaluated.

\section{Morphological studies}

Sample preparation for electron microscopy studies. The parental strain (A. niger UAM-GS1), and the mutants selected were inoculated in Petri dishes containing ML1 culture medium at $30^{\circ} \mathrm{C}$ during $48 \mathrm{hrs}$. After incubation, pieces of approximately one $\mathrm{cm}^{2}$ were cut and placed in 5 $\mathrm{mL}$ vials. A $5 \%$ glutaraldehyde solution in $0.1 \mathrm{M}$ phosphate buffer $\mathrm{pH} 7.3$, was added to carry out a primary fixing of the cells. The samples were then washed with buffer until complete glutaraldehyde scent removal. Samples were placed in $1 \%$ osmium tetraoxide in phosphate buffer $0.1 \mathrm{M}$, $\mathrm{pH} 7.3$, during $2 \mathrm{hrs}$. After this time, osmium tetraoxide was removed and the preparations washed with phosphate buffer. Samples were dehydrated in several stages with the addition of diluted acetone at different concentrations (30, $40,50,70,80,90$ and $100 \% \mathrm{v} / \mathrm{v}$ ), washing twice at $30 \mathrm{~min}$ intervals. The samples were then placed in aluminium capsules, fixed with colloidal coal, and dried to the critical point using a Samdri-780B equipment.

Covering with coal and gold. The fixed sample was evaporated under vacuum using a Baltec SCD050 equipment, followed by sample recovery with gold ions. Microscopic observations of samples were carried out in a Zellss DSM 940 A scanning electron microscope.

\section{Statistical analysis}

From the raw data, a simple product moment correlation coefficient (Pearson's correlation) was calculated. The data were subject to analysis of variance and the sample means tested for significant differences using the multiple intervals test (Duncan). This was carried out using the statistical package SPSS 9.0.

\section{RESULTS AND DISCUSSION}

$\mathrm{LD}_{50}$

After UV radiation of a spore suspension containing $1 \times 10^{7}$ spores $/ \mathrm{mL}, 50 \%$ lethality was reached after $3 \mathrm{~min}$. This result agrees with that reported by Loera-Corral and Viniegra-González (1998), for Aspergillus niger strains.

\section{Choice of the type of cellophane paper}

The cellophane paper used for the determination of fungal colony growth and enzymatic activity was chosen according to the growth characteristics and size of the colonies (Trinci, 1973). The relatively high tearing resistance and bursting strength of cellophane paper were also important considerations. For colony growth and size, 
Table 4. Sporulation level and spore viability of the selected strains.

\begin{tabular}{|c|c|c|c|}
\hline $\begin{array}{c}\text { Aspergillus niger } \\
\text { strains }\end{array}$ & $\begin{array}{c}\text { Incubation time } \\
(\mathbf{h r s})\end{array}$ & $\begin{array}{c}\text { Sporulation level } \\
\left(\text { Spores } \mathbf{~ m}^{-1} \text { ) }\right.\end{array}$ & $\begin{array}{c}\text { Spore viability } \\
(\%)\end{array}$ \\
\hline UAM-GS1 & 96 & $2.45 \times 10^{8} \pm 5 \times 10^{\prime}$ & $43 \pm 1$ \\
\hline GS1-S059 & 96 & $3.61 \times 10^{8} \pm 2 \times 10^{7}$ & $41 \pm 2$ \\
\hline GS1-S067 & 144 & $1.42 \times 10^{8} \pm 3 \times 10^{7}$ & $36 \pm 2$ \\
\hline
\end{tabular}

the sweet cellophane types 300 and 400 allowed a better $A$. niger growth (quantified as the colony diameter increase), after $48 \mathrm{hrs}$ of incubation at $30^{\circ} \mathrm{C}$. On the other hand, sweet cellophane types 400 and 500, showed the most suitable handling properties. Therefore, sweet cellophane 400 was chosen for further experiments.

\section{First strain selection}

The first selection of mannanase hyper producer mutants was conducted using a mutagenesis time of $3 \mathrm{~min}$, with four replicates. From these experiments, 84 strains were obtained. The diameter of the hydrolysis zone was determined for each one in triplicate. The strains whose hydrolysis zone was larger than that of the parental strain, were selected for the next experiments. Five hyper producer strains were obtained after the first selection, which showed the biggest ratio colony diameter/hydrolysis zone, compared to the parental strain (Table 1).

\section{Second selection}

The different standard enzyme concentrations used, made it possible to confirm the linearity of the relationship between enzymatic activity and area of the hydrolysis zone. The second selection was performed using this standard curve. The diameter of the hydrolyses zones produced by the enzymatic crude extracts from the SSF of the first selection mutants, were transformed to enzyme activity, using the above mentioned method. According to Table 2, the mutant strains showing more enzymatic activity were those labelled GS1-S059 and GS1-S067. These strains also showed the largest relationship between diameter of hydrolysis zone and colony diameter. These strains were used to perform our physiological and morphological studies.

\section{Physiological studies}

Colony radial extension rate. It was not possible to appreciate differences among the results obtained for colony growth experiments of the tested strains. The colonies radial extension rates $\left(\mathrm{Kr}, \mathrm{mm} \mathrm{d}^{-1}\right)$ were determined by plotting their length increment $(\mathrm{mm})$ versus time (d). From the data of the wild type and the two mutants (GS1-S059 and GS1-S067), linear regression analysis was conducted to give the mean $\mathrm{Kr}$ values. Analysis of variance was used to test significant difference among treatments, while the Duncan test was performed to evaluate which $\mathrm{Kr}$ values where significantly different with $P<0.05$ (Table 3, second column). The strain UAM-GS1 was significantly different from strain GS1-S067, but similar to the strain GS1-S059. The Kr value of strain GS1S067 was 1.17 times higher than that obtained for strain UAM-GS1. A colony $\mathrm{Kr}$ value may be considered an indication of the speed of microbial growth and its invasive capacity. Regarding the biomass growth rate [g biomass $\left./\left(\mathrm{cm}^{2} \mathrm{~h}\right)\right]$, the strain GS1-S067 increased 1.16 times faster than strain UAM-GS1 (Table 3, third column). Trinci (1971), found that $\mathrm{Kr}$ is proportional to the maximum specific growth rate measured in submerged cultures. Thus, the mutant GS1-S067 is promising from the point of view of its use in SSF. In this type of fermentation, it is a requirement that the microorganism used should show a high invasive capacity to avoid contamination (ViniegraGonzález, 1997).

Spore production. In this experiment, samples were taken every $24 \mathrm{hrs}$. One notorious difference among the strains was an important delay in the sporulation time of strain GS1-S067, where spore production was observed until 144 hrs of incubation. Despite strain GS1-S067 showed a sporulation level 1.72 times smaller than strain UAM-GS1, there were small differences in the spore production levels among the tested strains (Table 4). Strain GS1-S059 showed the largest spore production. A delay in sporulation time could be beneficial, since longer fermentation times can result in increased enzyme production, leaving few spores in the fermented product, leading to its safe handling. However, this phenomenon might be due to either the mutation process, or the effect of Bengal rose added to the culture media to slow down biomass growth for easier colony count.

Table 5. Enzyme activity profile of the selected strains.

\begin{tabular}{|c|c|c|c|}
\hline \multirow{2}{*}{$\begin{array}{c}\text { Aspergillus } \text { niger } \\
\text { strains }\end{array}$} & \multicolumn{3}{|c|}{ Enzyme activity (U L $\mathbf{~}^{-1}$ ) } \\
\cline { 2 - 4 } & Mannanase & Cellulase & Xylanase \\
\hline UAM-GS1 & 154 & 98 & 403 \\
\hline GS1-S059 & 501 & 363 & 314 \\
\hline GS1-S067 & 438 & 260 & 403 \\
\hline
\end{tabular}


Enzymatic profile. The results of the enzymatic profile are shown in Table 5. Compared to the wild strain, mannanase activity increased 3.26 times for strain GS1-S059, and 2.85 times for strain GS1-S067. Cellulase production increased 3.70 times for strain GS1-S059, and 2.65 times for the mutant GS1-S067, as compared to the parental strain. The highest enzymatic activity increase of the mutant strains corresponded to xylanase, where strains GS1-S059 and GS1-S067 showed increases of 6.19 and 4.82 times that of the parental strain, respectively. Thus, mutant strains GS1S059 and GS1-S067 significantly increased their levels of xylanase and cellulase production, improving in this way their potential industrial applications. These enzymes may be used in the bio-pulping processes (Ratto and Poutanen, 1988; Buchert et al. 1992), to increase digestibility of fodder and poultry feed (Wong and Saddler, 1993; Saki et al. 2005), fruit juice clarification and vegetable oil extraction (Sunna and Antranikian, 1997). Pearson's correlation analysis conducted on the enzymatic profile indicated a strong positive linear relationship between any two of the three enzyme activities ( $r \geq 0.939$ with a 0.01 significance level, 2-tailed). According to these results, if the mannanase activity increased, enzyme activity levels for cellulase and xylanase also increased. We attributed this effect to possible changes in the promoter zones of the genes coding for these enzymes due to the ultraviolet exposure. This radiation might have deregulated the transcription of the mRNA corresponding to these enzymes, leading to an increased secretion production. Since ultraviolet radiation affects mainly the hydrogen bonds of pyrimidic bases (cytosine + thymine; $\mathrm{C}+\mathrm{T}$ ) the most vulnerable regulatory sequences must have been those containing the highest concentration of $\mathrm{C}+\mathrm{T}$. It can be hypothesized that mannanase, xylanase and cellulase production might be under the control of the same regulon. From an analysis of the promoters sequence of the genes coding for mannanase, cellulase and xylanase reported for several microorganisms (Table 6), it was observed that at least in $80 \%$ of those sequences the percentage of T-A links is predominant. This fact suggests that the promoter zone was strongly affected by the UV radiation and it might have affected the mechanism of hemicellulolytic and cellulolytic enzymes expression. The mutants produced here can therefore be used with advantage in processes were both hemicellulose and cellulose hydrolysis is required, such as in the degradation of municipal organic wastes.

The major system responsible for carbon repression in Aspergillus is mediated by the carbon catabolite repressor protein CreA (Ruijter and Visser, 1997). CreA is a zinc finger protein which binds to specific sites in the promoters (SYGGRG) of a wide range of target genes, including xylanolytic (Shroff et al. 1996). Thus, more experiments should be conducted on the growth of the mutant strains obtained here, using various carbon and nitrogen sources to associate potential creA gene mutations. This could give more information about the possible deregulation observed for the three enzymes tested. However, there is also the possibility that the transcriptional activator $\mathrm{X} \ln R$ may

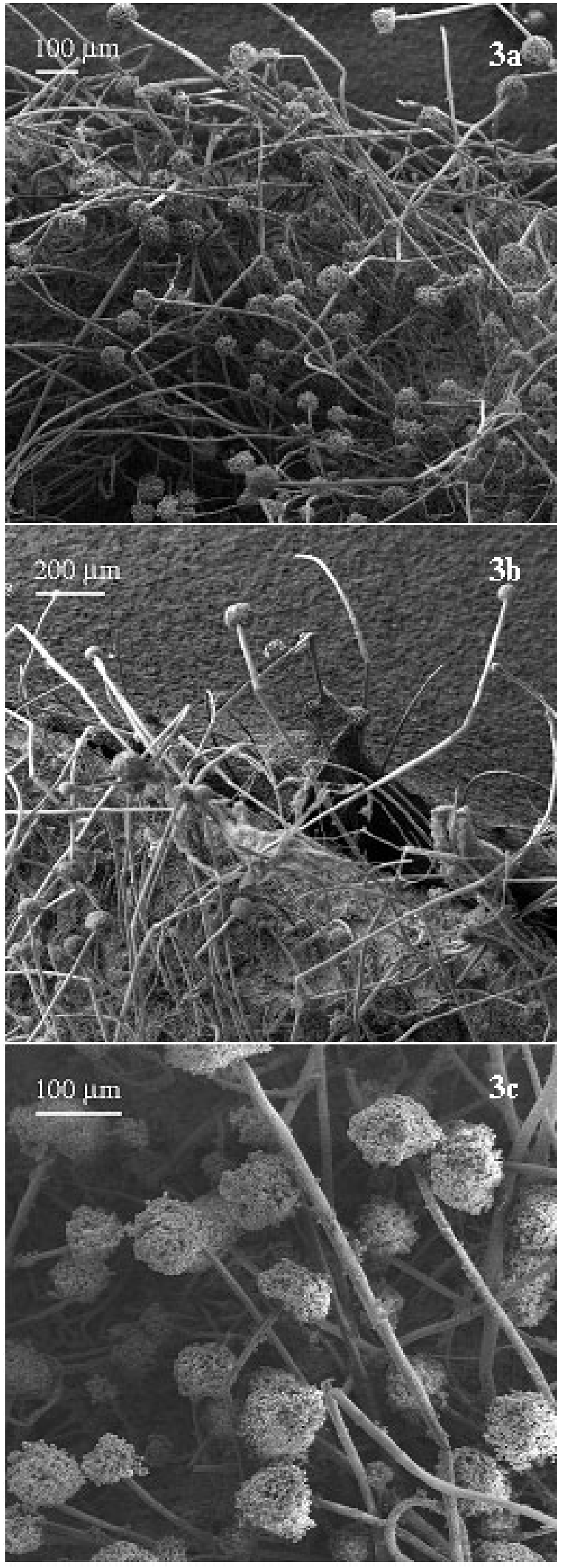

Figure 3. Scanning electron micrograph of hypha from:

(a) A. niger parental.

(b) mutant strains GS1-059.

(c) mutant strains GS1-067. 
Table 6. Promoters sequence analysis of the genes coding for mannanase, xylanase and cellulase reported for several microorganisms (GeneBank).

\begin{tabular}{|c|c|c|c|c|c|}
\hline \multicolumn{2}{|l|}{ Mannanase } & \multicolumn{2}{|l|}{ xylanase } & \multicolumn{2}{|l|}{ cellulase } \\
\hline Microorganism & $\begin{array}{l}\mathrm{T}-\mathrm{A} \\
(\%)\end{array}$ & Microorganism & $\begin{array}{l}\text { T-A } \\
(\%)\end{array}$ & Microorganism & $\begin{array}{l}\text { T-A } \\
(\%) \\
\end{array}$ \\
\hline $\begin{array}{l}\text { Lycopersicon esculentum } \\
\text { (AY102168) }\end{array}$ & 74.29 & $\begin{array}{l}\text { Clostridium thermocellum } \\
\text { (M67438) }\end{array}$ & 75.62 & $\begin{array}{l}\text { Cochliobolus carbonum } \\
\text { (AF336799) }\end{array}$ & 55.00 \\
\hline $\begin{array}{l}\text { Bacillus circulans } \\
\text { (AY623903) }\end{array}$ & 73.57 & $\begin{array}{l}\text { Bacillus halodurans } \\
\text { (AF534180) }\end{array}$ & 72.50 & $\begin{array}{l}\text { Thermoascus aurantiacus } \\
\text { EGI(eg) gene } \\
\text { (AF478686) }\end{array}$ & 53.89 \\
\hline $\begin{array}{l}\text { Lactuca sativa } \\
\text { (AJ315978) }\end{array}$ & 66.89 & $\begin{array}{l}\text { Bacillus subtilis bglS gene } \\
\text { (Z46945) }\end{array}$ & 66.84 & $\begin{array}{l}\text { T. koningii } \\
\text { (X69976) }\end{array}$ & 52.92 \\
\hline $\begin{array}{l}\text { Cellvibrio japonicus (man B) } \\
\text { (AY187034) }\end{array}$ & 64.14 & $\begin{array}{l}\text { Bacillus subtilis eglS gene } \\
\text { (Z29076) }\end{array}$ & 66.15 & $\begin{array}{l}\text { Thermoascus aurantiacus } \\
\text { (cbh) gene (AF478686) }\end{array}$ & 51.44 \\
\hline $\begin{array}{l}\text { Dictyoglomus thermophilum } \\
\text { (AF013989) }\end{array}$ & 59.17 & $\begin{array}{l}\text { Cellvibrio japonicus } \\
\text { (Z48927) }\end{array}$ & 64.44 & $\begin{array}{l}\text { Aspergillus nidulans } \\
\text { (AF420020) }\end{array}$ & 50.00 \\
\hline $\begin{array}{l}\text { Cellvibrio japonicus (man C) } \\
\text { (AJ187033) }\end{array}$ & 55.79 & $\begin{array}{l}\text { Paenibacillus sp } \\
\text { (AJ938162) }\end{array}$ & 63.08 & $\begin{array}{l}\text { Pleurotus sajor-caju } \\
\text { (AY050518) }\end{array}$ & 49.64 \\
\hline $\begin{array}{l}\text { Agaricus bisporus } \\
\text { (AJ278996) }\end{array}$ & 52.20 & $\begin{array}{l}\text { Bacillus firmus } \\
\text { (AY376352) }\end{array}$ & 59.64 & $\begin{array}{l}\text { Talaromyces emersonii } \\
\text { (AF439935) }\end{array}$ & 44.86 \\
\hline $\begin{array}{l}\text { Bacillus circulans gen alfa } \\
\text { (AB024331) }\end{array}$ & 50.29 & $\begin{array}{l}\text { Penicillium funiculosum } \\
\text { (AJ312295) }\end{array}$ & 52.83 & $\begin{array}{l}\text { Melanocarpus albomyces } \\
\text { (AJ515705) }\end{array}$ & 30.67 \\
\hline $\begin{array}{l}\text { Trichoderma reesei } \\
\text { (L253110) }\end{array}$ & 48.38 & $\begin{array}{l}\text { Scytalidium thermophilum } \\
\text { (AB114442) }\end{array}$ & 47.71 & & \\
\hline $\begin{array}{l}\text { R.marinus } \\
\text { (X90947) }\end{array}$ & 38.47 & $\begin{array}{l}\text { Streptomyces thermoviolaceus } \\
\text { (X81045) }\end{array}$ & 44.23 & & \\
\hline
\end{tabular}

regulate xylanolytic, endoglucanase, arabinanase, and cellulolytic gene expression, as tested by van Peij et al. (1998). These authors analyzed the promoter region of these genes obtaining a binding site consensus sequence of GGCTAA. In addition, the presence of CCAAT boxes in the promoter regions and the involvement of HAP (heme activator protein)-like complexes in the regulation of xylanases and cellulases in Trichoderma reesei suggests that these systems might also be regulated by HAP-like complexes in Aspergillus (de Vries and Visser, 2001).

\section{Morphological studies}

Sporangium and spore diameter. The sporangium or conidia heads are characteristic to distinguish the different groups of Aspergillus. These heads are formed by conidiophores, vesicle, and a series of primary sterigma, followed by a second series of secondary sterigma of which the conidia or spores sprout. Structures for the parental strain and mutants are shown in Figure 1. All pictures were taken to the same magnification and working distance. An average of 20 measurements made in different fields were obtained. The mutant strains GS1-S059 and GS1-S067 (Figure $1 \mathrm{~b}$ and $1 \mathrm{c}$, respectively) showed the same structures at the sporangium level as the parental strain (Figure 1a). However, the mutant strains showed variations in the sporangium diameter in relation to the original strain (Table 7). From the Duncan test of multiple intervals, significant differences in the diameter of the sporangium of the mutant strains were found. Both mutant strains showed a significant $(P<0.05)$ increase in diameter, compared to the parental strain: 1.20 and 1.42 times for strains GS1-S059 and GS1-S067, respectively. Differences in the sporangium appearance were also observed. Studies on Aspergillus nidulans by Fujiwara et al.(2000), revealed that double disruption of $c h s A / c h s D$ and $c h s A / c h s C$ resulted in severe inhibition of conidiation, but only in the strain having the disrupted $c h s A / c h s C$ genes the conidiophores morphology was altered. On the other hand, the spores of the mutant strains (Figure 2b and c) showed a slightly bigger diameter than the parental strain (Figure 2a), being the biggest increase for strain GS1-S067 (1.13). From the Duncan method, the mutants showed a significantly $(P<0.05)$ larger area than the UAM-GS1 strain. Suzuki et al. (1991), found in $C$. tropicalis that mutation induced with UV rays modified not only the colonial morphology, but also affected the cellular morphology. Morphological changes have been described in bacteria and yeasts after the application of UV radiation (Suzuki et al. 1991).

Hyphal length. Filamentous fungi are commonly used in SSF processes because of their capacity to invade the substrate. Therefore, it is required that the microorganisms show a high invasive capacity to grow at the surface of the substrate. The possession of long and ramified hypha increases the number of interaction places with the substrate, being an interesting characteristic for a strain of high enzyme production. The mycelium structure of the 
Table 7. Morphology of the Aspergillus niger mutant and parental strains.

\begin{tabular}{|c|c|c|c|c|}
\hline $\begin{array}{c}\text { Aspergillus } \\
\text { niger strains }\end{array}$ & $\begin{array}{c}\text { Sporangium diameter } \\
(\mathrm{mm})\end{array}$ & $\begin{array}{c}\text { Spore diameter } \\
(\mathbf{m m})\end{array}$ & $\begin{array}{c}\text { Hypha length } \\
(\mathbf{m m})\end{array}$ & $\begin{array}{c}\text { Hypha diameter } \\
(\mathbf{m m})\end{array}$ \\
\hline GS1 & $45.28(\mathrm{a})$ & $3.78(\mathrm{a})$ & $404.6(\mathrm{a})$ & $9.8(\mathrm{a})$ \\
\hline GS1-S059 & $54.25(\mathrm{~b})$ & $3.88(\mathrm{a})$ & $814.6(\mathrm{~b})$ & $12.16(\mathrm{~b})$ \\
\hline GS1-S067 & $64.56(\mathrm{c})$ & $4.30(\mathrm{~b})$ & $492.6(\mathrm{a})$ & $13.26(\mathrm{~b})$ \\
\hline
\end{tabular}

Duncan Method $(P<0.05)$. Different letter indicates significant difference.

parental and mutants strains are shown in Figure 3, where the hypha and the sporangium (analyzed previously) can be observed. Results on the measurement of 20 independent hyphae diameters and length for the three strains are shown in Table 7. The hypha length and diameter of the mutant strains significantly changed $(P<0.05)$ compared to the parental strain, i.e., the length of the hyphae increased twice for strain GS1-S059. Data analysis showed that the highest hyphal polarity index (hyphal length/hyphal width) was observed for strain GS1-S059 and the lowest one was for the strain GS1-S067. Harris et al. (1999), observed that Aspergillus nidulans mutants decreased their hyphal polarity index in relation to the wild strain. Microscopic observations (data not shown) of copra paste fermented with the GS1-S059 mutant corroborate that this strain showed a massive invasive capacity toward the substrate probably due to its high hyphal polarity index. Hyphal ramification data were not included due to sampling problems, since the hyphae form very compact networks. The samples were taken directly from an agar plate, where intersecting colonial fragments of the strains were clearly observed using the electron microscope.

Relationship between physiological and morphological properties of $\boldsymbol{A}$. niger strains. Statistical analysis of the data on hypha length, sporangium diameter, and cellulase, xylanase and mannanase activities was carried out. The Pearson correlation analysis indicated that there was an acceptable linear relationship $(\mathrm{r} \geq 0.428$ with a 0.01 significance level, 2-tailed) between any of these variables as a function of mannanase activity. Data reported from many studies carried out with diverse materials indicate that the mutagenic effect of the UV rays is indirect and that it implies the formation of precursors and enzymes from damaged DNA. Harris et al. (1999) working with Aspergillus nidulans identified genes required for hyphal morphogenesis and suggested that hyp $A$, podB, and sepA genes were required for multiple aspects of hyphal morphogenesis. Remarkably, $\operatorname{pod} B$ and $\operatorname{sep} A$ genes were needed for organization of the cytoskeleton at sites of polarized growth. On the contrary, hyphal polarity during germination required proteins encoded by podC and podD genes.

Müller et al. (2002) studied the Aspergillus oryzae morphology and $\alpha$-amylase production during submerged cultivation in a wild-type strain (A1560) and in strains of in which chitin synthase $\mathrm{B}(\operatorname{chs} B)$ and chitin synthesis myosin A $(\operatorname{csm} A)$ have been disrupted $(\mathrm{ChsB} / \mathrm{G}$ and CM101). Despite hyphal tip extension rate of the mutant strains decreased and branching intensity did not show an expected pattern, $\alpha$-amylase productivity was not significantly different in the three strains.

The relationship between physiology, morphology and enzyme production, if any, is poorly understood. Our results using $A$. niger mutants, obtained using UV rays, showed enhanced hemicellulolytic enzyme production and a good linear relationship between enzyme production (mannanase, cellulase and xylanase) and morphology (hyphal length and sporangium diameter).

\section{ACKNOWLEDGMENTS}

Authors thank Dr. José D. Sepúlveda-Sánchez (Electron Microscopy Laboratory, Building "W" Environmental Science and Technology. UAM-I CENICA) for valuable help in the electron microscopy studies.

\section{REFERENCES}

BUCHERT, J.; KANTELINEN, A.; RATTO, M.; SIIKAAHO, M.; RANUA, M. and VIIKARI, L. Xylanases and mannanases in the treatment of pulp. In: KUWAHARA M. and SHIMADA M. eds. The 5th International Conference on Biotechnology in the Pulp and Paper Industry. Uni Publishers, Tokyo, Japan, 1992, p. 139-143.

DE VRIES, R.P. and VISSER, J. Aspergillus enzymes involved in degradation of plant cell wall polysaccharides. Microbiology and Molecular Biology Reviews, December 2001, vol. 65, no. 4, p. 497-522.

DOWNIE, Bruce; HILHORST, Henk W.M. and BEWLEY, J. Derek. A new assay for quantifying endo- $\beta$-mannanase activity using Congo red dye. Phytochemistry, July 1994, vol. 36, no. 4, p. 829-835.

FERRET, E.; SIMÉON, J.H.; MOLIN, P.; JORQUERA, H.; ACUÑA, G. and GIRAL R. Macroscopic growth of filamentous fungi on solid substrate explained by a microscopic approach. Biotechnology and Bioengineering, 1999 , vol.65, no. 5 , p. $512-522$.

FUJIWARA, M.; ICHINOMIYA, M.; MOTOYAMA, T.; HORIUCHI, H.; OHTA, A. and TAKAGI, M. Evidence that the Aspergillus nidulans class I and class II chitin synthase genes, chs $C$ and $c h s A$, share critical roles in hyphal wall integrity and conidiophore development. Journal of Biochemistry, 2000, vol. 127, no. 3, p. 359-366. 
HARRIS, Steven D.; HOFMANN, Amy F.; TEDFORD, Hugo W. and LEE, Maurice P. Identification and characterization of genes required for hyphal morphogenesis in the filamentous fungus Aspergillus nidulans. Genetics, March 1999, vol.151, no. 3, p. 10151025.

IWASHITA, Kazuhiro Recent studies of protein secretion by filamentous fungi. Journal of Bioscience and Bioengineering, December 2002, vol.94, no. 6, p. 530-535.

LOERA-CORRAL, Octavio and VINIEGRAGONZÁLEZ, Gustavo. Identification of growth phenotypes in Aspergillus niger pectinase over producing mutants using image analysis procedures. Biotechnology Techniques, November 1998, vol. 12, no. 11, p. 801-804.

MCCARTHY, Tracey C.; LALOR, Eoin; HANNIFFY, Orla; SAVAGE, Angela V. and TUOHY, Maria G. Comparison of wild-type and UV-mutant $\beta$-glucanaseproducing strains of Talaromyces emersonii with potential in brewing applications. Journal of Industrial Microbiology and Biotechnology, April 2005, vol. 32, no. 4, p. 125-134.

MONTIEL-GONZÁLEZ, Alba M.; VINIEGRAGONZÁLEZ, Gustavo; FERNÁNDEZ, Francisco J. and LOERA, Octavio. Effect of water activity on invertase production in solid state fermentation by improved diploid strains of Aspergillus niger. Process Biochemistry, October 2004, vol. 39, no. 12, p. 2085-2090.

MÜLLER, Christian; MCINTYRE, Mhairi; HANSEN, Kim and NIELSEN, Jens. Metabolic engineering of the morphology of Aspergillus oryzae by altering chitin synthesis. Applied and Environmental Microbiology, April 2002, vol. 68, no. 4, p. 1827-1836.

NELSON, Norton Photometric adaptation of the Somogyi method for the determination of glucose. The Journal of Biological Chemistry, 1944, vol. 153, no. 2, p. 375-380.

PAPAGIANNI, Maria. Fungal morphology and metabolite production in submerged mycelial process. Biotechnology Advances, January 2004, vol. 22, no. 3, p. 189-259.

PAREKH, S.; VINCI, V.A. and STROBEL, R.J. Improvement of microbial strains and fermentation processes. Applied Microbiology and Biotechnology, September 2000, vol.54, no. 3, p. 287-301.

PITT, John I. and HOCKING, Ailsa D. Fungi and Food Spoilage. $2^{\text {nd }}$ ed. Blackie Academic and Professional, London, 1997, 593 p. ISBN 0412554607.

RAIMBAULT, M. and ALAZARD, D. Culture method to study fungal growth in solid state fermentation. European Journal of Applied Microbiology and Biotechnology, 1980, vol. 9, no. 3, p. 199-209.
RATTO, M. and POUTANEN, K. Production of mannandegrading enzymes. Biotechnology Letters, 1988, vol. 10, no. 9, p. 661-664.

REGALADO, Carlos; GARCIA-ALMENDÁREZ, Blanca E.; VENEGAS-BARRERA, Luz M.; TÉLLEZ-JURADO, Alejandro; RODRIGUEZ-SERRANO, Gabriela; HUERTA-OCHOA, Sergio and WITAKER, John R. Production, partial purification and properties of endo- $\beta$ mannanases obtained by solid substrate fermentation of spend soluble coffee wastes and copra paste using Aspergillus oryzae and Aspergillus niger. Journal of the Science of Food and Agriculture, June 2000, vol. 80, no. 9, p. 1343-1350.

RUIJTER, George J.G. and VISSER, Jaap. Carbon repression in aspergilli. FEMS Microbiology Letters, June 1997, vol. 151, no. 2, p. 103-114.

SAKI, A.A.; MAZUGI, M.T. and KAMYAB, A. Effect of mannanase on broiler performance, lleal and in vitro protein digestibility, uric acid and litter moisture in broiler feeding. International Journal of Poultry Science, 2005, vol. 4, no. 1, p. 21-26.

SAMBROOK, J.; FRITSCH, E.F. and MANIATIS, T. Molecular cloning, a laboratory manual. $3^{\text {rd }}$ ed. Cold Spring Harbor Laboratory, Cold Spring Harbor Press, NY, 2000. 999 p. ISBN 0879695773.

SHROFF, R.A.; LOCKINGTON, R.A. and KELLY, J.M. Analysis of mutations in the creA gene involved in carbon catabolite depression in Aspergillus nidulans. Canadian Journal of Microbiology, September 1996, vol. 42, no. 9, p. 950-959.

SUNNA, A. and ANTRANIKIAN, G. Xylanolytic enzymes from fungi and bacteria. Critical Review in Biotechnology, 1997, vol. 17, no. 1, p. 39-67.

SUZUKI, Takahito; MIYAMAE, Yuri and ISHIDA, Ikuko. Variation of colony morphology and chromosomal rearrangement in Candida tropicalis pk 233. Journal of General Microbiology, January 1991, vol. 137, no. 1, p. 161-167.

TRINCI, A.P.J. Influence of the peripheral growth zone on the radial growth rate of the fungal colonies. Journal of General Microbiology, 1971, vol.67, p. 325-344.

TRINCI, A.P.J. The hyphal Growth Unit of wild type and spreading colonial mutants of Neurospora crassa. Archives of Microbiology, 1973, vol.91, no. 2, p. 127-136.

VAN PEIJ, N.N.M.E.; GIELKENS, M.M.C.; DE VRIES, R.P.; VISSER, J. and DE GRAAFF, L.H. The transcriptional activator $X \ln R$ regulates both xylanolytic and endoglucanase gene expression in Aspergillus niger. Applied and Environmental Microbiology, October 1998, vol. 64 , no. 10 , p. 3615-3619. 
VINIEGRA-GONZÁLEZ, Gustavo. Solid state fermentation: Definition, characteristics, limitations and monitoring. In: ROUSSOS, S; LOSANE, B.K; RAIMBAULT, M. and VINIEGRA-GONZÁLEZ, G. eds. Advances in Solid State Fermentation, Kluwer Academic Publishers Dordredcht, 1997, p 5-22. ISBN 0792347323.

VINIEGRA-GONZÁLEZ, Gustavo. Strategies for the selection of mold strains geared to produce enzymes on solid substrates. In: GALINDO, E. and RAMÍREZ O.T. eds. Advances in Bioprocess Engineering II. Kluwer Academic Publishers, 1998, p. 123-136. ISBN 0792349237.

VINIEGRA-GONZÁLEZ, Gustavo; FAVELA-TORRES, Ernesto; AGUILAR, Cristóbal N.; ROMERO-GÓMEZ, Sergio J.; DÍAZ-GODÍNEZ, Gerardo and AGUR, Christopher. Advantages of fungal enzyme production in solid-state over liquid fermentation systems. Biochemical Engineering Journal, 2003, vol.13, no. 2-3, p. 157-167.

WONG, K.K.Y. and SADDLER, J.N. Application of hemicellulases in the food, feed and pulp and paper industries. In: COUGHLAN M.P. and HAZLEWOOD, G.P. eds. Hemicellulose and Hemicellulases. Portland Press, London, 1993, p. 127-143. ISBN 1855780364. 